\title{
Long noncoding RNA SNHG6 mainly functions as a competing endogenous RNA in human tumors
}

\author{
Hui-shan Wang ${ }^{1}$, Wen Zhang ${ }^{1}$, Han-long Zhu' ${ }^{1}$, Quan-peng Li ${ }^{2}$ and Lin Miao ${ }^{1,2^{*}}$ (D)
}

\begin{abstract}
Increased expression of the small nucleolar RNA host gene 6 (SNHG6) has been reported in different cancers, such as hepatocellular carcinoma, colorectal cancer, and lung cancer. The high expression level of SNHG6 is associated with tumor progression and poor prognosis. This paper provides an overview of recent studies on the oncogenic role and potential clinical utilities of SNHG6. Upregulated SNHG6 arrests tumor cell cycle and reduces apoptosis but promotes migration, invasion, metastasis, epithelial-mesenchymal transition (EMT), and chemoresistance in tumors. Mechanically, SNHG6 primarily sponges tumor suppressor microRNA (miRNA), functioning as a competing endogenous RNA. Once sponged, miRNA is unable to degrade, silence, or hamper the translation of its downstream, mostly oncogenic genes, ultimately driving cancer-related processes. Thus, SNHG6 might serve as a biomarker for cancer diagnosis and prognosis.
\end{abstract}

Keywords: Long non-coding RNA, SNHG6, Competing endogenous RNA, Tumors

\section{Background}

With technical progress in sequencing technologies, an increasing number of noncoding RNAs (ncRNAs) have been discovered in the last several years. Long ncRNA (lncRNA), > 200 nucleotides in length, has been reported to participate in a variety of biological processes, such as regulation of gene expression, subcellular architecture, and stabilization of protein complexes [1]. The role of lncRNA in physiology and pathophysiology was also reported [2]. Mechanistically, IncRNA often sponges many different types of miRNAs, acting as competing endogenous RNA (ceRNA) to realize its function. ceRNAs are transcripts competing for shared microRNA (miRNA) by complementary sequences [3]. MicroRNAs (miRNAs), a class of small ncRNAs typically 22 nucleotides in length, usually bind to the $3^{\prime}$-untranslated region of the target-gene mRNA, and once sponged, miRNA is unable to repress target mRNA translation or induce mRNA degradation [4]. The hypothesis of "ceRNA" was posed officially in 2011 when Salmena et al. expounded that RNA transcripts, similar to mRNAs, transcribed pseudogenes or lncRNAs containing miRNA-response elements (MREs), function as ceRNA and de-repress the activity of other RNAs with similar MREs by competing for the same miRNA in the available miRNA pool [5].

The subject of ncRNA functioning as ceRNA in tumor formation and progression has been extensively explored, and many ncRNAs have been investigated as miRNA sponges in a variety of cancers. Such ncRNAs include GAS5 in pancreatic cancer [6], ZFAS1 in colon adenocarcinoma [7], and MALAT1 in endometrioid endometrial carcinoma [8]. This review will summarize the most

\footnotetext{
${ }^{*}$ Correspondence: linmiao@njmu.edu.cn

${ }^{1}$ Nanjing Medical University, Nanjing, Jiangsu Province, China

Full list of author information is available at the end of the article
}

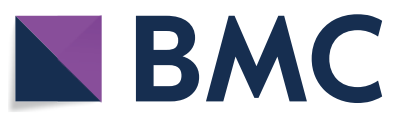

(c) The Author(s) 2020. This article is licensed under a Creative Commons Attribution 4.0 International License, which permits use, sharing, adaptation, distribution and reproduction in any medium or format, as long as you give appropriate credit to the original author(s) and the source, provide a link to the Creative Commons licence, and indicate if changes were made. The images or other third party material in this article are included in the article's Creative Commons licence, unless indicated otherwise in a credit line to the material. If material is not included in the article's Creative Commons licence and your intended use is not permitted by statutory regulation or exceeds the permitted use, you will need to obtain permission directly from the copyright holder. To view a copy of this licence, visit http://creativeco mmons.org/licenses/by/4.0/. The Creative Commons Public Domain Dedication waiver (http://creativecommons.org/publicdomain/ zero/1.0/) applies to the data made available in this article, unless otherwise stated in a credit line to the data. 
recent findings on SNHG6, focusing on the effect of its upregulation and its role as ceRNA in tumor progression.

\section{SNHG6-A novel player in human tumors}

Human SNHG6 (Ensembl: ENSG00000245910) is the housekeeping gene of the 5/TOP family, which can encode two kinds of noncoding RNAs, namely, U87 C/D box snoRNA, synthesized by the second intron, and SNHG6 RNA, encoded by exons. SNHG6 is located in chromosome 8q13.1 and consists of five transcripts (i.e., SNHG6-201 to SNHG6-205). SNHG6 is localized preferentially in the cytoplasm by cytoplasmic and nuclear RNA fractions from some cancer cells, such as hepatocellular cells and colorectal cancer cells $[9,10]$. According to recent studies, SNHG6 is overexpressed in cancer tissues compared with the corresponding noncancerous tissues as well as in different cancer cell lines [11-13]. Upregulated SNHG6 relates to advanced tumor progression and short survival in patients $[14,15]$. SNHG6 is responsible for cell proliferation, migration, invasion, reduced apoptosis in vitro, increased tumor size, and increased metastases in vivo $[16,17]$.

The next section will mainly discuss the information gained in recent years about the role of SNHG6 in some relative frequent cancer types, such as hepatocellular carcinoma (HCC), colorectal cancer (CRC), gastric cancer (GC), esophageal squamous cell carcinoma (ESCC), lung adenocarcinoma (LUAD), breast cancer (BC), bladder cancer, glioma, and osteosarcoma.

\section{Hepatocellular carcinoma (HCC)}

SNHG6 is upregulated in HCC tissues and cell lines. Overexpressed SNHG6 is tightly related to tumor development and poor survival $[9,18]$. Cao et al. reported that five SNHG6 transcripts differentially expressed in HCC tissues, while only SNHG6-003 exerted an oncogenic function, which serves as ceRNA by binding to miR$26 \mathrm{a} / \mathrm{b}$, thereby regulating transforming growth factor- $\beta$ activated kinase 1, an oncogene of HCC [18]. Another study demonstrated that SNHG6 plays an oncogenic role in liver tumorigenesis by activating the TGF- $\beta 1 / \mathrm{SMAD}$ signaling pathway and upregulating zinc finger E-boxbinding homeobox1 (ZEB1) via effectively sponging miR101-3p, resulting in epithelial-mesenchymal transition (EMT) [9]. Chen et al. recently showed that SNHG6 promotes HCC cell proliferation via competitively binding let-7c-5p and thereby regulating the expression of c-Myc [19]. Besides, SNHG6 could also activate SERPINH1 expression by competitive binding to miR-139-5p in HCC, which is verified by Wu et al. [17]. Guo and his colleagues shed light on the role of SNHG6 in genome-wide hypomethylation in hepatocellular cells. They verified that SNHG6, negatively correlated with the steady-state
S-adenosylmethionine (SAMe) concentration in vivo and in vitro, suppressed MAT1A protein expression by activating the miR-1297/FUS pathway [20]. Methionine adenosyltransferase (MAT) are essential enzymes that catalyze SAMe formation, and MAT2A is expressed in the proliferating liver during dedifferentiation and in cancer, while MAT1A is expressed in quiescent adult hepatocytes [21, 22]. Interestingly, the effect of SNHG6 on genome-wide methylation was inhibited by exogenous SAMe within a certain concentration range, indicating the potential benefit of SAMe for treatment of liver cancer. In summary, these findings demonstrated that SNHG6 could promote progression of HCC by acting as a ceRNA from different aspects.

\section{Colorectal cancer (CRC)}

In the last 3 years, scholars have explored the role of SNHG6 in CRC. Generally, SNHG6 was found to be upregulated in CRC tissues and cell lines and responsible for high tumor grades and poor patient survival. Highly expressed SNHG6 could enhance CRC cell proliferation, invasion, and migration. SNHG6 could also act as miRNA sponge to induce the dysfunction of the following miRNAs: (a) miR-760 [23], (b) miR-101-3p [10, 12], (c) miR-214-3p [24], (d) miR-26a-5p, miR-26b-5p [24], and (e) miR-181a-5p [24]. Zhu et al. demonstrated the role of miR-760 in CRC. They illustrated that miR-760, as a direct target of SNHG6, could reverse the inhibitory effect of SNHG6 knockdown on CRC progression by targeting forkhead box $\mathrm{C} 1$ [23]. The relationship between SNHG6 and miR-101-3p is indentified by two study groups. In Wang's study, they found that SNHG6 sponges miR-101-3p, inducing an upregulated expression of ZEB1, which is a key transcription factor in EMT. They also proved that SNHG6 could activate the TGF- $\beta /$ Smad pathway by binding to UPF1 in CRC cells [10]. While Shao' data showed that SNHG6 could regulate the progression of CRC via modulating the expression levels of miR-101-3p and the activity of Wnt/beta-catenin signaling [12]. Xu et al. proved that SNHG6 could interact with miR-214 and miR-26a/b and regulate their common target-EZH2 [24], while another group also showed the relationship between SNHG6 and miR-26a. In their study, SNHG6 promotes chemoresistance of CRC cells through ULK1-induced autophagy by sponging miR-26a-5p [26]. For miR-181a-5p, Yu et al. demonstrated that E2F5, as a direct target of this miRNA, is upregulated, resulting in increased CRC proliferation by regulating the cell cycle [25]. Moreover, Li et al. proved that SNHG6 could directly suppress p21 expression by recruiting EZH2 to the p21 promoter in CRCs [27]. However, in Meng' study, they verified that SNHG6 was downregulated in colorectal cancer tissues, suppress ETS1 via the PI3K/AKT/ 
mTOR pathway to inhibit CRC cell proliferation and metastasis [28]. Due to only 30 colon tumors and adjacent non-tumor tissues samples were detected, we think the results is not so convincing compared with many other studies with positive results. From the above, the authors concluded that SNHG6 was acting in an oncogenic role by binding multiple miRNAs and abrogating its tumor-suppressive function in CRC progression.

\section{Gastric cancer (GC)}

Studies have reported some connections between SNHG6 and GC. Similar to its role in HCC, SNHG6 is upregulated in GC and its high expression influences cancer cell characteristics, such as cell growth, migration capacity, and EMT. Yan et al. [29] revealed that SNHG6promoted cell growth could be due to its influence on cell cycle through interacting with PRC2 and epigenetic silencing p27, whereas SNHG6-accelerated migration could be through miR-101-3p sponging, thereby regulating ZEB1. Li's study indicated that SNHG6 facilitates GC progression by upregulating p21 through activation of the JNK pathway and suppression of EZH2 [30]. Therefore, these data have revealed that SNHG6 plays an important role in progression of GC through targeting key promoters in the cell cycle such as P21 and P27.

\section{Esophageal squamous cell carcinoma (ESCC)}

Fan's and Zhang's groups both found that SNHG6 expression is significantly increased in ESCC tissues and is associated with tumor size and TNM stage [31, 32]. These two groups both found that SNHG6 knockdown can inhibit proliferative, colony-forming abilities, and induce the apoptosis of ESCC cells. They also concluded that SNHG6 exerts oncogenic function in ESCC and may be a potential diagnostic marker for this cancer. In $\mathrm{Du}$ ' study, they demonstrated that SNHG6 promoted the proliferation, migration, and invasion of ESCC cells through regulating miR-186-5p/HIF1 $\alpha$ axis [33]. Above all, the results may provide a novel therapeutic target-SNHG6 for ESCC. Besides, more functions and detailed molecular mechanisms of SNHG6 in ESCC need to be explored.

\section{Lung cancer (LC)}

Several studies all found that SNHG6 expression was also significantly increased in non-small cell lung cancer (NSCLC) tissues and cell lines and its high expression was correlated with malignant features of NSCLC. In Geng' study, knockdown of SNHG6 significantly depressed the proliferation vitality and migration activity of NSCLC cells in vitro. Research on mechanisms illustrated that SNHG6 regulates ETS1 signaling via miR-944 and miR181d-5p [34]. In Dong' study, SNHG6 significantly promoted proliferation and inhibited apoptosis of NSCLC cells. Mechanism research demonstrated that SNHG6 regulates miR-490-3p/RSF1 axis [35]. Li and his colleagues found that increased expression of SNHG6 was associated with pathological stage and lymph node infiltration, and acted as an independent prognostic factor of tumor recurrence in patients with NSCLC. Silencing SNHG6 expression repressed cell growth and invasion in vitro and in vivo. Mechanically, SNHG6 was identified to regulate CDYL expression by acting as a sponge of miR-101-3p [36]. More than that, Liang et al. found that SNHG6 expression is higher in lung adenocarcinoma (LAOD) tissues than in adjacent non-tumor tissues, and its overexpression is related to tumor development and poor survival in patients. Functionally and mechanically, SNHG6 promotes cell cycle progression, cell proliferation, migration, invasion, and EMT by acting as ceRNA via competitively binding to miR-26a-5p, thereby activating E2F7 [37]. To summarize, the authors demonstrated that SNHG6 were involved in progression of lung cancer by regulating multiple miRNAs, representing promising targeted therapeutic strategies against NSCLC.

\section{Breast cancer (BC)}

Recent TCGA data analysis showed that SNHG6 might serve as a potential prognostic marker for $\mathrm{BC}$ without further experimental validation [38]. Two study groups showed that high SNHG6 expression increases $\mathrm{BC}$ cell proliferation by targeting miR-26a-5p, and miR26a-5p targets respectively to MAPK6 [39] and VASP [40]. Therefore, the authors conclude that SNHG6 participates in BC development through the miR-26a-5p/ MAPK6 and miR-26a-5p/VASP pathway. Another group suggested that SNHG6 could also be involved in ionizing radiation-induced stress response in a tumor protein p53-dependent manner [41]. From these results, the authors concluded that SNHG6 was served as an oncogene by binding miR-26a in $\mathrm{BC}$ progression.

\section{Bladder cancer}

High expression of SNHG6 in bladder cancer cells was discovered by Wang et al. [42]. Their data suggested that overexpressed SNHG6 induces EMT through upregulating Snail1/2 and promotes migration and invasion of bladder cancer cells by sponging miR-125b, thereby activating the target gene of miR-125b-novel (nua) kinase family 1 (NUAK1), also known as ARK5. Thus, SNHG6 accelerates bladder cancer cell progression through miR125b/NUAK1 and miR-125b/Snail1/2 pathways.

\section{Glioma}

Meng et al. found that SNHG6 also upregulates in glioma tissues and cells compared with normal brain tissues and cells [43]. In their research, SNHG6 promotes glioma cell 


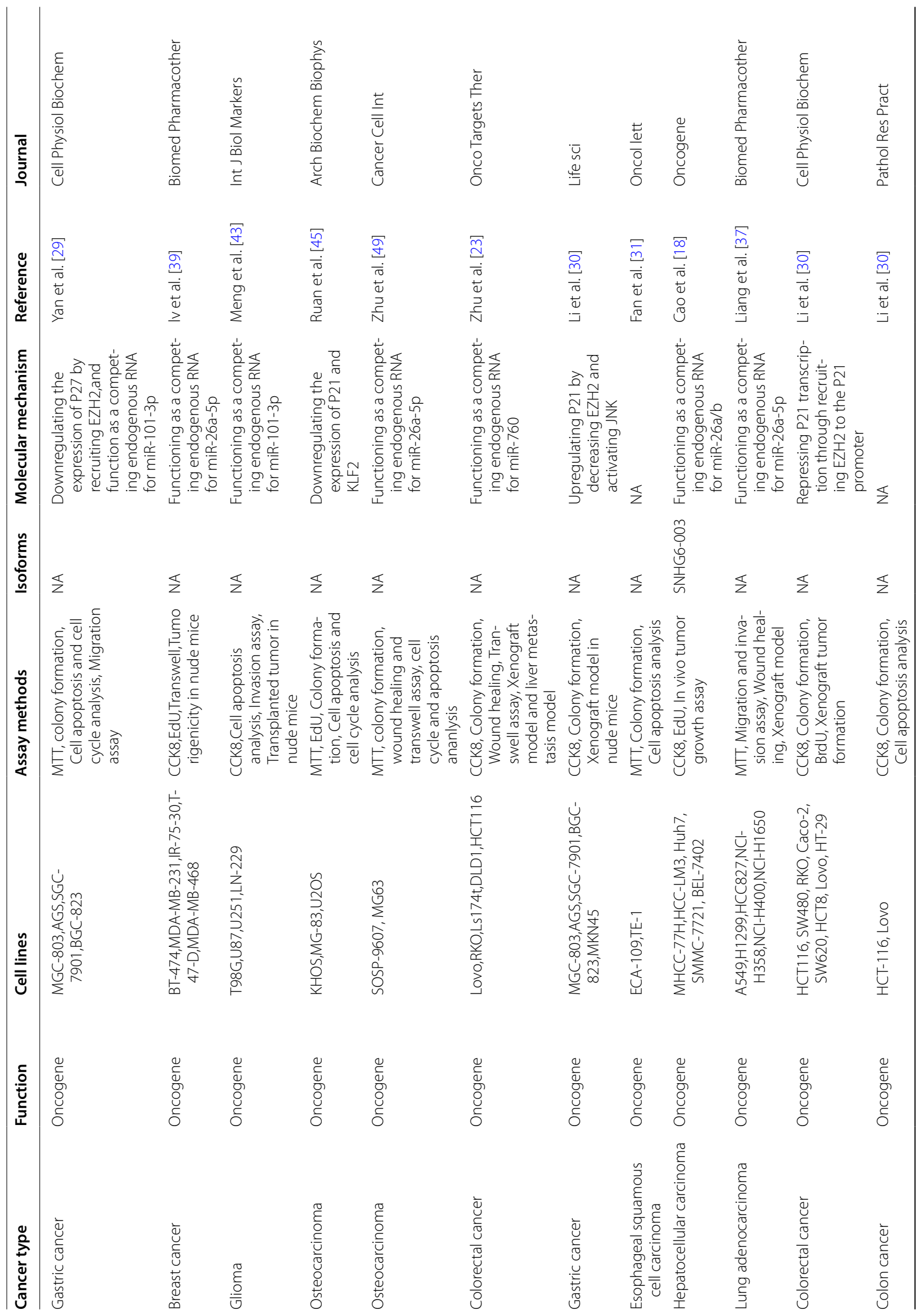




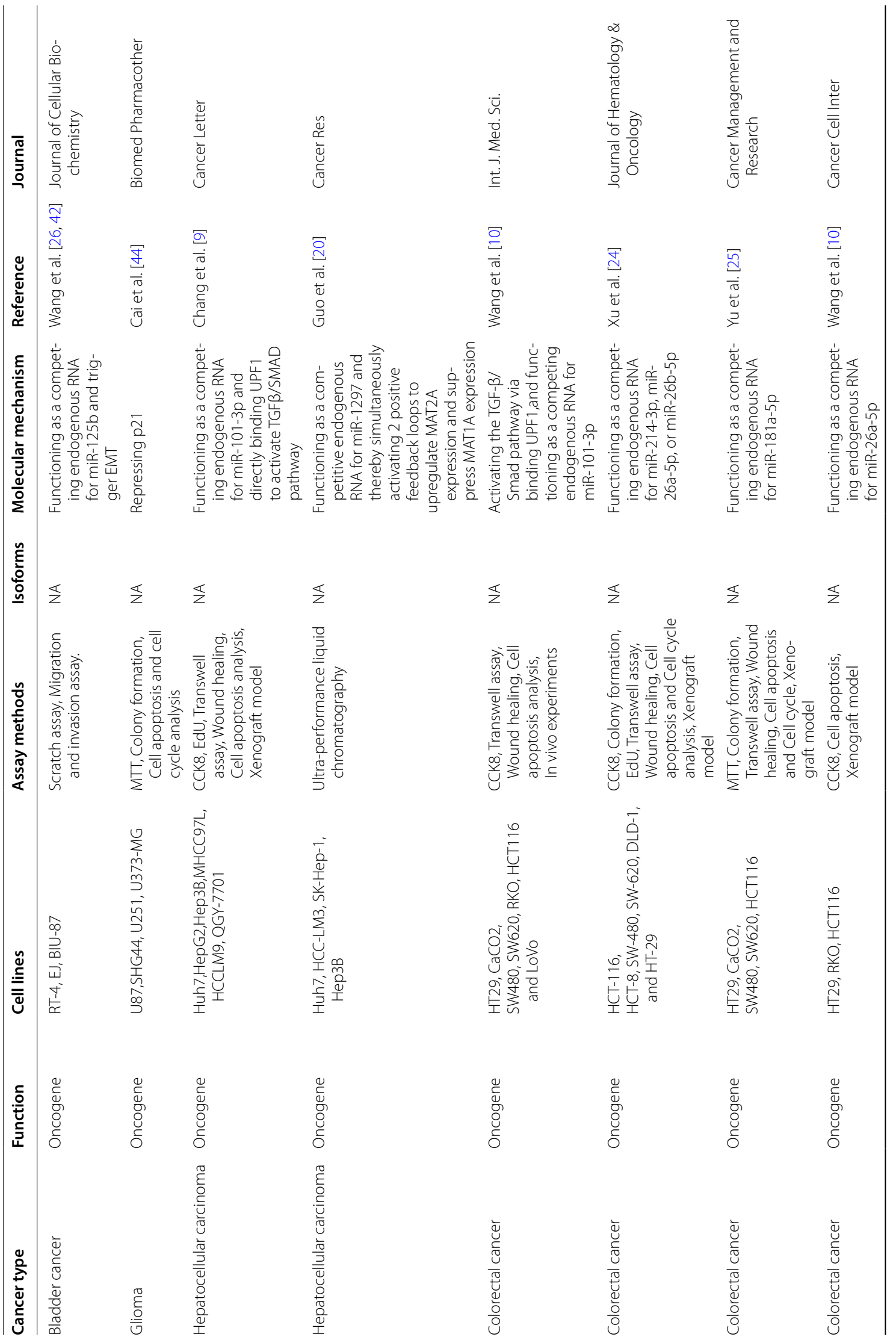




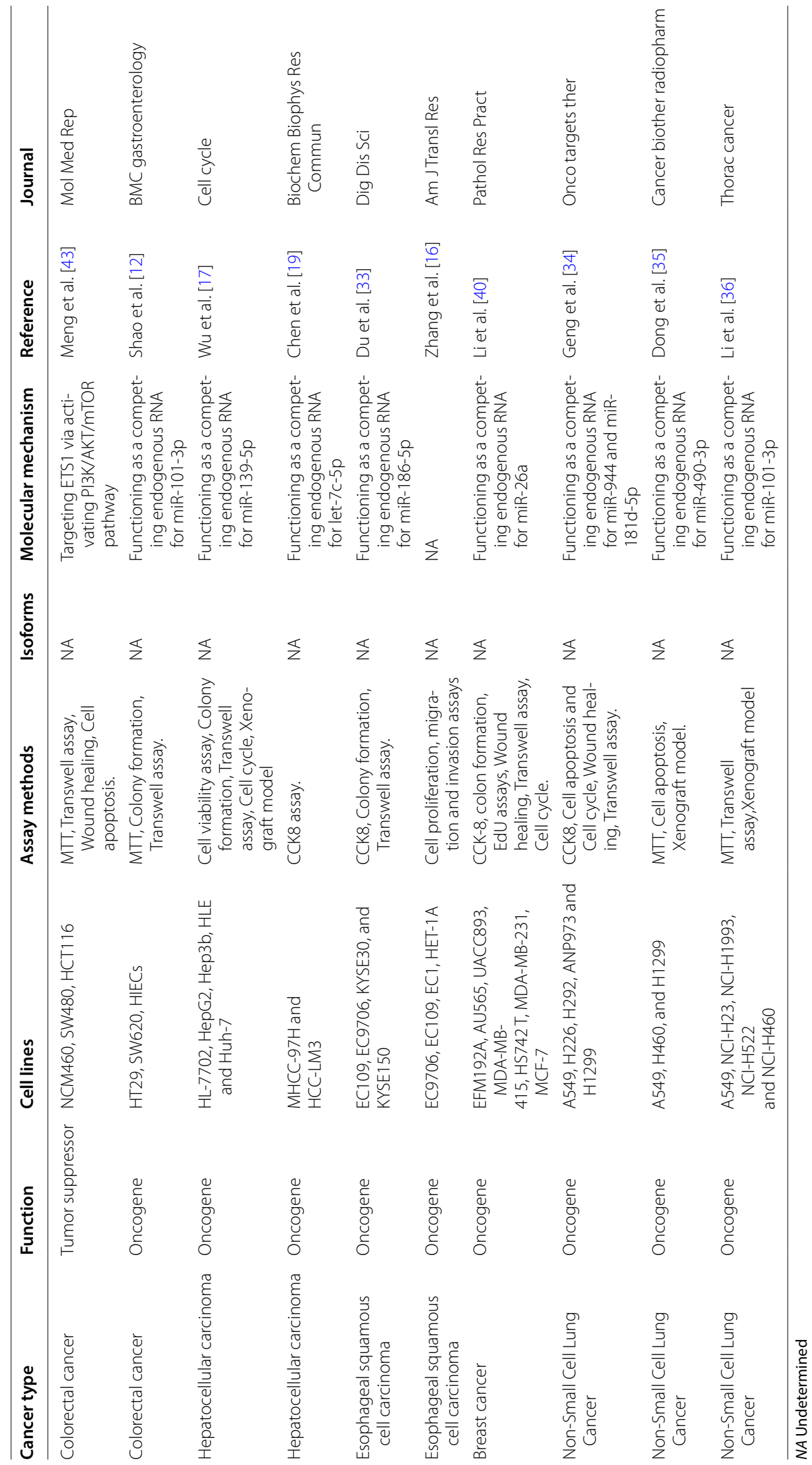




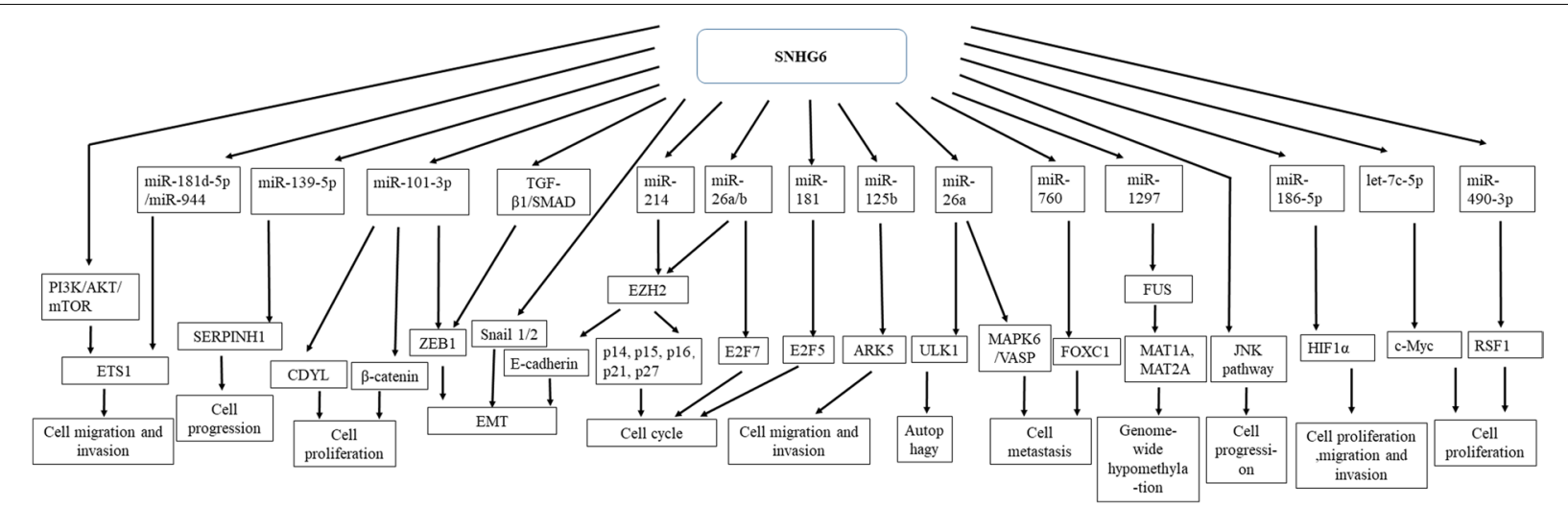

Fig. 1 The role and underlying molecular mechanisms of SNHG6 in multiple human cancers. SNHG6 could get involved in the progress of cell migration and invasion, cell metastasis, cell cycle, cell progression, EMT, autophagy and genome-wide hypomethyltion, mainly via the following mechanisms: (i) SNHG6 functions as miRNA sponges to antagonize the connections between multiple tumor suppressor miRNAs and their target mRNAs. (ii) SNHG6 acts as a scaffold RNA molecule by interacting with EZH2, a subunit of the polycomb repressive complex to influence the expression of downstream effectors of EZH2. (iii) SNHG6 activates JNK pathway, PI3K/AKT/mTOR and TGFB/SMAD pathway

proliferation, migration, and EMT and reduces apoptosis by downregulating miR-101-3p. Anti-miR-101-3p and miR-101-3p mimic rescue the effects of si-SNHG6 on cell malignancy. However, details about the target gene of miR-101-3p are not shown in this study. Another study carried out by Cai and his team workers detected that upregulated SNHG6 is responsible for glioma cell proliferation, which is consistent with Meng's results [44], while silencing SNHG6 can induce cell cycle arrest by upregulating $\mathrm{p} 21$.

\section{Osteosarcoma}

Ruan et al. revealed that upregulated SNHG6 predicts poor survival and advanced TNM stage for patients with osteosarcoma [45]. They investigated that si-SNHG6 represses cell proliferation by arresting cell cycle in the G0/G1 phase and inducing cell apoptosis. Mechanically, SNHG6 is negatively correlated with p21 and Kruppel Like Factor 2 (KLF2), which is a target gene interacting with ncRNAs in malignancies [46]. p21 and KLF2 play vital roles in osteosarcoma progression, such as miR95-3p/p21 axis [47], and involvement of KLF2 in drug resistance to doxorubicin [48]. In Zhu's study, they found that SNHG6 could competitively sponging miR-26a-5p thereby regulating ULK1, and induced cell apoptosis and autophagy by targeting caspase3 and ATF3 [49]. Thus, SNHG6 is involved in osteosarcoma progression and may serve as an oncogene.

\section{Conclusion and future perspectives}

In a variety of cancers, SNHG6 is highly expressed in cancer tissues in contrast to noncancerous tissues. SNHG6 is also upregulated in the investigated cancer cell lines. Overexpressed SNHG6 arrests cell cycle and reduces apoptosis but promotes migration, invasion, metastasis, EMT, and chemoresistance. The relevant clinicopathological features and underlying molecular mechanisms of SNHG6 in various cancers are summarized in Tables 1 and Fig. 1. The molecular mechanisms can be divided into three categories, as following: (i) SNHG6 functions as miRNA sponges to antagonize the connections between multiple tumor suppressor miRNAs and their target mRNAs. (ii) SNHG6 acts as a scaffold RNA molecule by interacting with EZH2, a subunit of the polycomb repressive complex to influence the expression of downstream effectors of EZH2. (iii) SNHG6 activates JNK pathway, PI3K/AKT/mTOR and TGF $\beta /$ SMAD pathway. These studies have focused only on tumor cell proliferation, apoptosis, invasion, and migration of these classic phenotypes, especially cell proliferation. Further studies are needed to explore the phenotypes of SNHG6 in tumors, such as tumor metabolism and immunity escape.

This review focuses on the role of SNHG6 as ceRNA and provide details about SNHG6, its sponging miRNAs, and target genes, which is summarized in Table 2. Given its contributions to cancer development, using SNHG6 and its targets has potential for diagnosis and treatment of cancer. In clinical practice, overexpressed SNHG6 could be a vital biomarker for diagnosis and prognosis of tumor patients. Nevertheless, the chemical stability of SNHG6 in biological samples (e.g., serum) remains 
Table 2 Details about SNHG6 functioning as ceRNA in tumorigenesis and tumor progression

\begin{tabular}{|c|c|c|c|c|c|c|}
\hline Cancer type & miRNA & $3^{\prime}-5^{\prime}$ sequence & PBS to SNHG6 & Experimental method & Target protein & References \\
\hline Gastric cancer & miR-101-3p & $\begin{array}{l}\text { AAGTCAATAGTGTCA } \\
\text { TGACAT }\end{array}$ & 12 & $\begin{array}{l}\text { Luciferase activity assay, } \\
\text { RIP, RNA pull down } \\
\text { assay }\end{array}$ & ZEB1 & Yan et al. [29] \\
\hline Breast cancer & miR-26a-5p & $\begin{array}{l}\text { TCGGATAGGACCTAATGA } \\
\text { ACTT }\end{array}$ & 8 & Luciferase activity assay & MAPK6 & Iv et al. [39] \\
\hline Glioma & miR-101-3p & $\begin{array}{l}\text { AAGTCAATAGTGTCA } \\
\text { TGACAT }\end{array}$ & 12 & Luciferase activity assay & NA & Meng et al. [43] \\
\hline Colorectal cancer & miR-760 & $\begin{array}{l}\text { AGGGGUGUCUGGGUC } \\
\text { UCGGC }\end{array}$ & 7 & $\begin{array}{l}\text { Dual luciferase reporter } \\
\text { assay }\end{array}$ & FOXC1 & Zhu et al. [23] \\
\hline Hepatocellular carcinoma & miR-26a & $\begin{array}{l}\text { CGGATAGGACCTAAT } \\
\text { GAACTT }\end{array}$ & 8 & $\begin{array}{l}\text { RIP, luciferase reporter } \\
\text { assays. }\end{array}$ & TAK1 & Cao et al. [18] \\
\hline Hepatocellular carcinoma & miR-26b & $\begin{array}{l}\text { TGGATAGGACTTAAT } \\
\text { GAACTT }\end{array}$ & 8 & $\begin{array}{l}\text { RIP, luciferase reporter } \\
\text { assays. }\end{array}$ & TAK1 & Cao et al. [18] \\
\hline Lung adenocarcinoma & miR-26a-5p & $\begin{array}{l}\text { TCGGATAGGACCTAATGA } \\
\text { ACTT }\end{array}$ & 8 & $\begin{array}{l}\text { Luciferase reporter and } \\
\text { RNA pull-down assays }\end{array}$ & E2F7 & Liang et al. [37] \\
\hline Bladder cancer & miR-125b & $\begin{array}{l}\text { UCACAAGUCAGGCUC } \\
\text { UUGGGAC }\end{array}$ & 8 & $\begin{array}{l}\text { Luciferase reporter gene } \\
\text { assay }\end{array}$ & Snail1/2 and NUAK1 & Wang et al. [42] \\
\hline Hepatocellular carcinoma & miR-101-3p & $\begin{array}{l}\text { AAGTCAATAGTGTCA } \\
\text { TGACAT }\end{array}$ & 9 & Luciferase assay & ZEB1 & Chang et al. [9] \\
\hline Hepatocellular carcinoma & miR-1297 & AAGTTCATCATTCCCT & 11 & Luciferase assay & MAT2A and FUS & Guo et al. [20] \\
\hline Colorectal cancer & miR-101-3p & NA & NA & qRT-PCR & ZEB1 & Wang et al. $[26,42]$ \\
\hline Colorectal cancer & $\operatorname{miR}-214-3 p$ & $\begin{array}{l}\text { UGACGGACAGACACG } \\
\text { GACGACA }\end{array}$ & 14 & $\begin{array}{l}\text { Luciferase reporter assay, } \\
\text { RNA pull-down assay, } \\
\text { ChIP, RIP }\end{array}$ & $\mathrm{EZH} 2$ & Xu et al. [24] \\
\hline Colorectal cancer & miR-26a-5p & $\begin{array}{l}\text { CGGATAGGACCTAAT } \\
\text { GAACTT }\end{array}$ & 8 & $\begin{array}{l}\text { Luciferase reporter assay, } \\
\text { RNA pull-down assay, } \\
\text { ChIP, RIP }\end{array}$ & $\mathrm{EZH} 2$ & Xu et al. [24] \\
\hline Colorectal cancer & miR-26b-5p & $\begin{array}{l}\text { TGGATAGGACTTAAT } \\
\text { GAACTT }\end{array}$ & 8 & $\begin{array}{l}\text { Luciferase reporter assay, } \\
\text { RNA pull-down assay, } \\
\text { ChIP, RIP }\end{array}$ & $\mathrm{EZH} 2$ & Xu et al. [24] \\
\hline Colorectal cancer & miR-181a-5p & $\begin{array}{l}\text { TGAGTGGCTGTCGCAACT } \\
\text { TACAA }\end{array}$ & 7 & Luciferase reporter assay & E2F5 & Yu et al. [25] \\
\hline Osteocarcinoma & miR-26a-5p & $\begin{array}{l}\text { TCGGATAGGACCTAATGA } \\
\text { ACTT }\end{array}$ & 8 & Luciferase reporter assay & ULK1 & Zhu et al. [49] \\
\hline Colorectal cancer & miR-101-3p & $\begin{array}{l}\text { AAGTCAATAGTGTCA } \\
\text { TGACAT }\end{array}$ & 13 & Luciferase reporter assay & $\beta$-catenin & Shao et al. [12] \\
\hline Colorectal cancer & miR-26a-5p & $\begin{array}{l}\text { CGGATAGGACCTAAT } \\
\text { GAACTT }\end{array}$ & 8 & $\begin{array}{l}\text { Dual-luciferase reporter } \\
\text { assay }\end{array}$ & ULK1 & Wang et al. [10] \\
\hline Hepatocellular carcinoma & miR-139-5p & $\begin{array}{l}\text { UGACCUCUGUGCACG } \\
\text { UGACAUCU }\end{array}$ & 7 & $\begin{array}{l}\text { Dual-luciferase reporter } \\
\text { assay,RIP }\end{array}$ & SERPINH1 & Wu et al. [17] \\
\hline Hepatocellular carcinoma & let-7c-5p & ATGGAG & 6 & Luciferase reporter assay & c-Myc & Chen et al. [19] \\
\hline $\begin{array}{l}\text { Esophageal squamous } \\
\text { cell carcinoma }\end{array}$ & miR-186-5p & $\begin{array}{l}\text { UCGGGUUUUCCUCU- } \\
\text { UAAGAAAC }\end{array}$ & 13 & $\begin{array}{l}\text { Luciferase reporter assay, } \\
\text { RNA Pull-Down Assay }\end{array}$ & HIF1a & Du et al. [33] \\
\hline Breast cancer & miR-26a-5p & $\begin{array}{l}\text { GAUUACUUGAACGAG } \\
\text { GCCAC }\end{array}$ & 8 & $\begin{array}{l}\text { Luciferase assay, RNA } \\
\text { Pull-Down Assay,RIP }\end{array}$ & VASP & Li et al. [27] \\
\hline $\begin{array}{l}\text { Non-Small Cell Lung } \\
\text { Cancer }\end{array}$ & miR-181d-5p & $\begin{array}{l}\text { UGGGUGGCUGUUGUU } \\
\text { ACUUACAA }\end{array}$ & 10 & $\begin{array}{l}\text { Dual-Luciferase Reporter } \\
\text { Assay, RIP }\end{array}$ & ETS1 & Geng et al. [34] \\
\hline $\begin{array}{l}\text { Non-Small Cell Lung } \\
\text { Cancer }\end{array}$ & miR-944 & $\begin{array}{l}\text { GAGUAGGCUACAUGU } \\
\text { UAUUAAA }\end{array}$ & 13 & $\begin{array}{l}\text { Dual-Luciferase Reporter } \\
\text { Assay, RIP }\end{array}$ & ETS1 & Geng et al. [34] \\
\hline $\begin{array}{l}\text { Non-Small Cell Lung } \\
\text { Cancer }\end{array}$ & miR-490-3p & $\begin{array}{l}\text { GUCGUACCUCAGGAG } \\
\text { GUCCAAC }\end{array}$ & 7 & Luciferase reporter assay & RSF1 & Dong et al. [35] \\
\hline $\begin{array}{l}\text { Non-Small Cell Lung } \\
\text { Cancer }\end{array}$ & miR-101-3p & $\begin{array}{l}\text { AAGTCAATAGTGTCA } \\
\text { TGACAT }\end{array}$ & 13 & $\begin{array}{l}\text { Dual-luciferase reporter } \\
\text { assay,RIP }\end{array}$ & CDYL & Li et al. [36] \\
\hline
\end{tabular}

PBS predicted binding sites. NA Undetermined, ChIP Chromatin Immunoprecipitation, RIP RNA Immunoprecipitation 
unclear. Although extensive researches have been carried out on the contribution of SNHG6 to cancer biology, diagnosis, and prognosis, further studies are needed to shed light on its possible therapeutic intervention.

\section{Acknowledgements \\ Not applicable.}

\section{Authors' contributions}

LM and HW conceived the idea, LM also approved the final version of the manuscript; QL and HZ did the literature search; HW wrote the manuscript, WZ helped revising the manuscript. All authors read and approved the final manuscript.

\section{Funding}

This work was supported by Project of Standard Diagnosis and Treatment of Key Disease of Jiangsu Province (BE2015722).

\section{Availability of data and materials}

Data sharing not applicable to this article as no datasets were generated or analysed during the current study.

\section{Ethics approval and consent to participate}

Not applicable.

\section{Consent for publication}

Not applicable.

\section{Competing interests}

The authors declare that they have no competing financial interests.

\section{Author details}

${ }^{1}$ Nanjing Medical University, Nanjing, Jiangsu Province, China. ${ }^{2}$ Medical Center for Digestive Diseases, The Second Affiliated Hospital of Nanjing Medical University, 121 Jiangjiayuan, Nanjing 210011, Jiangsu Province, China.

Received: 26 August 2019 Accepted: 28 May 2020

Published online: 06 June 2020

\section{References}

1. Gutschner T, Richtig G, Haemmerle M, Pichler M. From biomarkers to therapeutic targets-the promises and perils of long non-coding RNAs in cancer. Cancer Metastasis Rev. 2018;37(1):83-105.

2. Del VF, Lee GH, Hawezi J, Bhome R, Pugh S, Sayan E, et al. Long noncoding RNAs within the tumour microenvironment and their role in tumour-stroma cross-talk. Cancer Lett. 2018;421:94-102.

3. Qi X, Zhang DH, Wu N, Xiao JH, Wang X, Ma W. ceRNA in cancer: possible functions and clinical implications. J Med Gent. 2015;52(10):710-8.

4. Bartel DP. MicroRNAs: target recognition and regulatory functions. Cell. 2009;136(2):215-33.

5. Salmena L, Poliseno L, Tay Y, Kats L, Pandolfi PP. A ceRNA hypothesis: the Rosetta Stone of a hidden RNA language. Cell. 2011;146(3):353-8.

6. Liu B, Wu S, Ma J, Yan S, Xiao Z, Wan L, et al. IncRNA GAS5 Reverses EMT and Tumor Stem Cell-Mediated Gemcitabine Resistance and Metastasis by Targeting miR-221/SOCS3 in Pancreatic Cancer. Mol Ther Nucleic Acids. 2018:13:472-82.

7. Chen X, Zeng K, Xu M, Hu X, Liu X, XuT, et al. SP1-induced IncRNA-ZFAS1 contributes to colorectal cancer progression via the miR-150-5p/vEGFA axis. Cell Death Dis. 2018;9(10):982.

8. Li Q, Zhang C, Chen R, Xiong H, Qiu F, Liu S, et al. Disrupting MALAT1/ miR-200c sponge decreases invasion and migration in endometrioid endometrial carcinoma. Cancer Lett. 2016;383(1):28-40.

9. Chang L, Yuan Y, Li C, Guo T, Qi H, Xiao Y, et al. Upregulation of SNHG6 regulates ZEB1 expression by competitively binding miR-101-3p and interacting with UPF1 in hepatocellular carcinoma. Cancer Lett. 2016;383(2):183-94.
10. Wang X, Lai Q, He J, Li Q, Ding J, Lan Z, et al. LncRNA SNHG6 promotes proliferation, invasion and migration in colorectal cancer cells by activating TGF-beta/Smad signaling pathway via targeting UPF1 and inducing EMT via regulation of ZEB1. Int J Med Sci. 2019;16(1):51-9.

11. Wu Y, Deng Y, Guo Q, Zhu J, Cao L, Guo X, et al. Long non-coding RNA SNHG6 promotes cell proliferation and migration through sponging miR-4465 in ovarian clear cell carcinoma. J Cell Mol Med. 2019;23(8):5025-36.

12. Shao $\mathrm{Q}, \mathrm{Xu}$ J, Deng $\mathrm{R}$, Wei W, Zhou B, Yue C, et al. SNHG 6 promotes the progression of Colon and Rectal adenocarcinoma via miR-101-3p and Wnt/beta-catenin signaling pathway. BMC Gastroenterol. 2019;19(1):163.

13. Ansari H, Shahrisa A, Birgani YT, Birgani MT, Hajjari M, Asl JM. Long noncoding RNAs in colorectal adenocarcinoma; an in silico analysis. Pathol Oncol Res. 2019;25(4):1387-94.

14. Zhao S, Zhu H, Jiao R, Wu X, Ji G, Zhang X. Prognostic and clinicopathological significance of SNHG6 in human cancers: a meta-analysis. BMC Cancer. 2020;20(1):77.

15. Wu Y, Zhang Y, Zhu X, Liu H. The Association of Long Non-Coding RNA SNHG6 Expression with Clinicopathological Features and Prognosis in Cancer. Clin Lab. 2019. https://doi.org/10.7754/Clin.Lab.2019.190346.

16. Zhang M, Duan W, Sun W. LncRNA SNHG6 promotes the migration, invasion, and epithelial-mesenchymal transition of colorectal cancer cells by miR-26a/EZH2 axis. Onco Targets Ther. 2019;12:3349-60.

17. Wu G, Ju X, Wang Y, Li Z, Gan X. Up-regulation of SNHG6 activates SER$\mathrm{PINH} 1$ expression by competitive binding to miR-139-5p to promote hepatocellular carcinoma progression. Cell Cycle. 2019;18(16):1849-67.

18. Cao C, Zhang T, Zhang D, Xie L, Zou X, Lei L, et al. The long non-coding RNA, SNHG6-003, functions as a competing endogenous RNA to promote the progression of hepatocellular carcinoma. Oncogene. 2017;36(8):1112-22.

19. Chen $S$, Xie C, Hu X. IncRNA SNHG6 functions as a ceRNA to upregulate c-Myc expression via sponging let-7c-5p in hepatocellular carcinoma. Biochem Biophys Res Commun. 2019:519(4):901-8.

20. Guo T, Wang H, Liu P, Xiao Y, Wu P, Wang Y, et al. SNHG6 Acts as a Genome-Wide Hypomethylation Trigger via Coupling of miR-1297-Mediated S-Adenosylmethionine-Dependent Positive Feedback Loops. Cancer Res. 2018;78(14):3849-64.

21. Lu SC, Mato JM. S-adenosylmethionine in liver health, injury, and cancer. Physiol Rev. 2012;92(4):1515-42.

22. Lu SC, Mato JM. Role of methionine adenosyltransferase and S-adenosylmethionine in alcohol-associated liver cancer. Alcohol. 2005;35(3):227-34.

23. Zhu Y, Xing Y, Chi F, Sun W, Zhang Z, Piao D. Long noncoding RNA SNHG6 promotes the progression of colorectal cancer through sponging miR760 and activation of FOXC1. Onco Targets Ther. 2018;11:5743-52

24. Xu M, Chen X, Lin K, Zeng K, Liu X, Xu X, et al. IncRNA SNHG6 regulates EZH2 expression by sponging miR-26a/b and miR-214 in colorectal cancer. J Hematol Oncol. 2019;12(1):3.

25. Yu C, Sun J, Leng X, Yang J. Long noncoding RNA SNHG6 functions as a competing endogenous RNA by sponging miR-181a-5p to regulate E2F5 expression in colorectal cancer. Cancer Manag Res. 2019;11:611-24.

26. Wang X, Lan Z, He J, Lai Q, Yao X, Li Q, et al. LncRNA SNHG6 promotes chemoresistance through ULK1-induced autophagy by sponging miR26a-5p in colorectal cancer cells. Cancer Cell Int. 2019;19:234.

27. Li Z, Qiu R, Qiu X, Tian T. SNHG6 promotes tumor growth via repression of P21 in colorectal cancer. Cell Physiol Biochem. 2018:49(2):463-78.

28. Meng S, Jian Z, Yan X, Li J, Zhang R. LncRNA SNHG6 inhibits cell proliferation and metastasis by targeting ETS1 via the PI3K/AKT/mTOR pathway in colorectal cancer. Mol Med Rep. 2019;20(3):2541-8.

29. Yan K, Tian J, Shi W, Xia H, Zhu Y. LncRNA SNHG6 is associated with poor prognosis of gastric cancer and promotes cell proliferation and EMT through epigenetically silencing p27 and Sponging miR-101-3p. Cell Physiol Biochem. 2017;42(3):999-1012.

30. LiY, Li D, Zhao M, Huang S, Zhang Q, Lin $\mathrm{H}$, et al. Long noncoding RNA SNHG6 regulates p21 expression via activation of the JNK pathway and regulation of EZH2 in gastric cancer cells. Life Sci. 2018;208:295-304.

31. Fan RH, Guo JN, Yan W, Huang MD, Zhu CL, Yin YM, et al. Small nucleolar host gene 6 promotes esophageal squamous cell carcinoma cell proliferation and inhibits cell apoptosis. Oncol Lett. 2018;15(5):6497-502.

32. Zhang Y, Li R, Ding X, Zhang K, Qin W. Upregulation of long non-coding RNA SNHG6 promote esophageal squamous cell carcinoma cell malignancy and its diagnostic value. Am JTransl Res. 2019;11(2):1084-91. 
33. Du F, Guo T, Cao C. Silencing of long noncoding RNA SNHG6 inhibits esophageal squamous cell carcinoma progression via miR-186-5p/HIF1alpha axis. Dig Dis Sci. 2019. https://doi.org/10.1007/s10620-019-06012-8.

34. Geng H, Li S, Xu M. Long noncoding RNA SNHG6 functions as an oncogene in non-small cell lung cancer via modulating ETS1 signaling. Onco Targets Ther. 2020;13:921-30.

35. Dong Z, Liu H, Zhao G. Long noncoding RNA SNHG6 promotes proliferation and inhibits apoptosis in non-small cell lung cancer cells by regulating miR-490-3p/RSF1 axis. Cancer Biother Radiopharm. 2020. https://doi. org/10.1089/cbr.2019.3120.

36. Li K, Jiang Y, Xiang X, Gong Q, Zhou C, Zhang L, et al. Long noncoding RNA SNHG6 promotes the growth and invasion of non-small cell lung cancer by downregulating miR-101-3p. Thorac Cancer. 2020;11(5):1180-90.

37. Liang $R$, Xiao G, Wang M, Li X, Li Y, Hui Z, et al. SNHG6 functions as a competing endogenous RNA to regulate E2F7 expression by sponging miR-26a-5p in lung adenocarcinoma. Biomed Pharmacother. 2018;107:1434-46.

38. Ding $X$, Zhang $Y$, Yang $H$, Mao W, Chen B, Yang S, et al. Long non-coding RNAs may serve as biomarkers in breast cancer combined with primary lung cancer. Oncotarget. 2017;8(35):58210-21.

39. Lv P, Qiu X, Gu Y, Yang X, Xu X, Yang Y. Long non-coding RNA SNHG6 enhances cell proliferation, migration and invasion by regulating miR-26a-5p/MAPK6 in breast cancer. Biomed Pharmacother 2019;110:294-301.

40. Li K, Ma YB, Tian YH, Xu XL, Gao Y, He YQ, et al. Silencing IncRNA SNHG6 suppresses proliferation and invasion of breast cancer cells through miR26a/VASP axis. Pathol Res Pract. 2019;215(10):152575.

41. Chaudhry MA. Expression pattern of small nucleolar RNA host genes and long non-coding RNA in X-rays-treated lymphoblastoid cells. Int J Mol Sci. 2013;14(5):9099-110.
42. Wang C, Tao W, Ni S, Chen Q. Upregulation of IncRNA snoRNA host gene 6 regulates NUAK family SnF1-like kinase-1 expression by competitively binding microRNA-125b and interacting with Snail1/2 in bladder cancer. J Cell Biochem. 2019;120(1):357-67.

43. Meng Q, Yang BY, Liu B, Yang JX, Sun Y. Long non-coding RNA SNHG6 promotes glioma tumorigenesis by sponging miR-101-3p. Int J Biol Markers. 2018;33(2):148-55.

44. Cai G, Zhu Q, Yuan L, Lan Q. LncRNA SNHG6 acts as a prognostic factor to regulate cell proliferation in glioma through targeting p21. Biomed Pharmacother. 2018;102:452-7.

45. Ruan J, Zheng L, Hu N, Guan G, Chen J, Zhou X, et al. Long noncoding RNA SNHG6 promotes osteosarcoma cell proliferation through regulating p21 and KLF2. Arch Biochem Biophys. 2018;646:128-36.

46. Lian Y, Yan C, Ding J, Xia R, Ma Z, Hui B, et al. A novel IncRNA, LL22NC03N64E9.1, represses KLF2 transcription through binding with EZH2 in colorectal cancer. Oncotarget. 2017:8(35):59435-45.

47. Zhao $X$, Yang $Y, X$ U J, Luo $Y, X$ in $Y$, Wang Y. Downregulation of microRNA95-3p suppresses cell growth of osteosarcoma via CDKN1A/p21 expression. Oncol Rep. 2018;39(1):289-97.

48. Rajkumar T, Yamuna M. Multiple pathways are involved in drug resistance to doxorubicin in an osteosarcoma cell line. Anticancer Drugs. 2008;19(3):257-65

49. Zhu X, Yang G, Xu J, Zhang C. Silencing of SNHG6 induced cell autophagy by targeting miR-26a-5p/ULK1 signaling pathway in human osteosarcoma. Cancer Cell Int. 2019:19:82.

\section{Publisher's Note}

Springer Nature remains neutral with regard to jurisdictional claims in published maps and institutional affiliations.
Ready to submit your research? Choose BMC and benefit from:

- fast, convenient online submission

- thorough peer review by experienced researchers in your field

- rapid publication on acceptance

- support for research data, including large and complex data types

- gold Open Access which fosters wider collaboration and increased citations

- maximum visibility for your research: over $100 \mathrm{M}$ website views per year

At $\mathrm{BMC}$, research is always in progress.

Learn more biomedcentral.com/submissions 